\title{
Evaluation of Personality Traits of Physical Education Teachers Working in Secondary Schools and High Schools in Çanakkale According to Their Sports Branch*
}

\author{
Erdal Demir \\ Canakkale Onsekiz Mart University, Çanakkale, Turkey
}

\begin{abstract}
The sampling of the present study consists of 92 volunteer physical education teachers (59 male and 33 female) who work at state and private primary schools (of the Ministry of Education) in Canakkale in the academic year 2013-2014. To identify the personality traits of the participants, Personality Inventory (PERI) was utilized. PERI consists of five factors, namely, openness to experience, conscientiousness, extraversion, agreeableness, and neuroticism. The inventory was administered face-to-face. Specialities and personality traits of physical education teachers were compared for the purpose of the study. Kruskal-Wallis test and Mann-Whitney $U$ test were utilized to analyze the obtained data. The results revealed a significant correlation between specialities and personality traits of physical education teachers only in terms of emotional stability and compatibility domains $(p<0.05)$, but not of other three factors. Moreover, no statistically significant difference was discovered between sports types (team or individual sports) and personality traits of physical education teachers $(p>0.05)$.
\end{abstract}

Keywords: physical education, personality, personality traits, specialization in sports, individual sports, team sports

\section{Introduction}

Personality derived from the word persona in Latin, meaning mask worn by theatre players according to their role (Köknel, 2005; Zel, 2001; Hjelle \& Ziegler, 1976). Ancient Greek theatre players wore a mask to their faces and this mask contained roles of the players. Roles in these plays belonged to life and thus they were accepted to be the view of the first thoughts about personality (Hjelle \& Ziegler, 1976).

Personality is defined as consistent behavior patterns stemming from the individuals themselves and inter personal processes (Burger, 2006). Larsen and Buss (2008), on the other hand, defined personality as psychological traits group. This group is made of psychological mechanics, inner world, persistent adaptations, gender interaction, adaptation, psychological thoughts, and physical and social surrounding of individuals.

We can define personality based on the above given definitions as a way of individuals revealing themselves in their daily lives in relationships established with their surroundings, and by inner personality processes.

Interpretation of personality in five dimensions started in the 1960s. Personality psychologists agree on the

\footnotetext{
* This paper was presented at The V Europen Conference on Social and Behavioral Sciences.

Erdal Demir, Ph.D., assistant professor, College of Physical Education and Sport, Canakkale Onsekiz Mart University.
} 
"big five factors" as meaningful and practical classification towards the end of the 1980s (Hackett \& Saha, 1999). These five fundamental dimensions are extroversion, harmony, responsibility, clarity, and emotional stability (Dubrin, 1994; Berry, 1998; Hughes, 1996; Barrick \& Mount, 1991; Ertuğrul, 2000; Erden, 2009; Friedman \& Schustack, 1999; Özdemir \& Yalın, 2000).

For liking the classes, teachers are effective rather than the classes themselves, and physical education class is among the most interested classes (Eken, 2008). Secondary school and high school students expressed physical education classes as fun and joyful (Tannehil \& Zakrajsek, 1993). Çamlica (2008) reported that physical education classes develop secondary school students' leadership skill and self-reliant sense, improve love and respect for themselves and environment, assist in complying with the inner class and school rules, and enable balanced nutrition habits. Elementary school and secondary school students have positive attitude toward physical education classes (Şişko \& Demirhan, 2002; Güllü, 2007).

Based on these explanations, it is important to determine personality traits of physical education teachers in terms of determining standards of personality traits of ideal physical education teachers, and carrying out some education activities for removal of undesired personality traits in physical education teachers.

The purpose of the present study is to scrutinize the relationship between personality traits of physical education teachers serving in secondary schools and high schools in Çanakkale and their sports branches and sports types.

\section{Method}

Definition and clarification of a current state is presented in the study. Therefore, the research was carried out in the survey model. The survey model is a research approach aiming to depict a situation, which existed in the past or is currently existing, as it appears (Karasar, 2003).

Data collection tools were applied by the researcher by face-to-face technique. The research group was interviewed in an appropriate time at leisure and candidly. Application directive and vital matters were explained to the participants orally for achieving association and consistency.

The research group was made of 92 physical education teachers serving in state and private secondary schools and high schools connected to the Ministry of Education in the counties of Çanakkale Center, Ayvacık, Biga, Bayramiç, Lapseki, Ezine, Çan, Yenice, Gelibolu, and Gökceada. For forming the study group, variables that could affect the research, such as accessibility, attitude of the school administration, and approach of physical education teachers, were considered, schools were visited, and the survey was applied. Physical education teachers serving in public schools in exchange of salary were also included in the research because they have the same statue with physical education teachers working in private schools.

Numerical distributions are 31 physical education teachers in the soccer branch, 13 basketball, 10 athleticism, 17 volleyball, eight swimming, four racket sports, three handball, four gymnastics, and two defense sports. Moreover, when distribution of physical education teachers is examined according to individual or team sports, 69.6\% $(N=64)$ physical education teachers sported in team sports (basketball, soccer, volleyball, and handball), and 30.4\% ( $N=28)$ physical education teachers sported in individual sports (athleticism, swimming, racket sports, gymnastics, and defense sports) (see Table 1).

The mean age of the research group was 38.7 years old. Of the 92 physical education teachers, $35.9 \%(N=$ $33)$ of them were female, and $64.1 \%(N=59)$ of them were male. The distribution based on school type was 91.3\% $(N=84)$ served in public schools and $8.7 \%(N=8)$ served in private schools. The distribution based on 
school level was $51.1 \%(N=47)$ served in secondary schools and $48.9 \%(N=45)$ served in high schools (see Table 2).

Table 1

Frequency and Percentage Values of Physical Education Teachers According to Their Branches and Sports Types

\begin{tabular}{|c|c|c|c|c|c|}
\hline Sports type & $f$ & $\%$ & Branch & $f$ & $\%$ \\
\hline \multirow{4}{*}{ Team sports } & \multirow{4}{*}{64} & \multirow{4}{*}{69.6} & Soccer & 31 & 33.7 \\
\hline & & & Basketball & 13 & 14.1 \\
\hline & & & Volleyball & 17 & 18.5 \\
\hline & & & Handball & 3 & 3.3 \\
\hline \multirow{5}{*}{ Individual sports } & \multirow{5}{*}{28} & \multirow{5}{*}{30.4} & Athleticism & 10 & 10.9 \\
\hline & & & Swimming & 8 & 8.7 \\
\hline & & & Racket sports & 4 & 4.3 \\
\hline & & & Gymnastics & 4 & 4.3 \\
\hline & & & Defense sports & 2 & 2.2 \\
\hline Total & 92 & 100 & Total & 92 & 100 \\
\hline
\end{tabular}

Table 2

Frequency and Percentage Values of Physical Education Teachers According to Gender, School Type, and School Level

\begin{tabular}{llcc}
\hline & & $f$ & $\%$ \\
\hline \multirow{2}{*}{ Gender } & Male & 59 & 64.1 \\
& Female & 33 & 35.9 \\
\hline \multirow{2}{*}{ School type } & Public schools & 84 & 91.3 \\
& Private schools & 8 & 8.7 \\
\hline \multirow{2}{*}{ School level } & Secondary schools & 47 & 51.1 \\
& High schools & 45 & 48.9 \\
\hline
\end{tabular}

Data forms and personality inventories were used in the research as data collection tools. The data form was created by the researcher and included information on the gender, sports branch, service year, school type, and school level of the participants (see Tables 1 and 2). For the evaluation of personality traits of the physical education teachers, Personality Inventory (PERI) short form developed by Sevinç (2005) was used. The short form of the inventory was made of 25 statements and arranged in a 5-point Likert scale. It encompasses openness to experience, responsibility consciousness, extroversion, compatibility, and emotional stability dimensions of personality. From reliability analyses of PERI short form, it was found that internal consistency coefficients of the dimensions were between 0.71 and 0.87 , and test-retest coefficients were between 0.88 and 0.93 . Thus, it was in high reliability category (Sevinç, 2005).

Definitive statistics of the data and their distribution were performed and significance level was taken as 0.05. For determining differentiation of survey scores, Kruskal-Wallis and Mann-Whitney $U$ tests were performed.

\section{Findings}

In the examination of personality traits of the physical education teachers and sports branches average scores, it was observed that handball players received the lowest average score in the characteristic of openness 
to experience, and racket sports (tennis and badminton) players received the highest score. In the sub-dimension of emotional stability, on the other hand, gymnasts received the lowest average score in all sub-dimensions, and again tennis and badminton players received the highest score with an average of 4.08. In extroversion and compatibility traits, handball players received the lowest score and physical education teachers who sport defense sports received the highest scores. Defense sports players received the highest average score in responsibility consciousness and swimmers received the lowest score (see Table 3 ).

It was observed that in the research group, in the responsibility consciousness property, team sports $(\overline{\bar{x}}=4.46)$ and individual sports $(\overline{\bar{x}}=4.43)$ received the highest average scores. In the emotional stability, extroversion, compatibility, and responsibility consciousness personality traits, average of team sports had higher scores than individual sports. However, in the sub-dimension of openness to experience, individual sports had higher averages than team sports (see Table 4).

Table 3

Average Scores of Personality Traits of Physical Education Teachers Based on Their Sports Branches

\begin{tabular}{|c|c|c|c|c|c|c|}
\hline \multirow{3}{*}{ Branches } & \multirow{3}{*}{$N$} & \multicolumn{5}{|c|}{ Personality factors } \\
\hline & & $\begin{array}{l}\text { Openness to } \\
\text { experience }\end{array}$ & $\begin{array}{l}\text { Emotional } \\
\text { stability }\end{array}$ & Extroversion & Compatibility & $\begin{array}{l}\text { Responsibilty } \\
\text { consciousness }\end{array}$ \\
\hline & & $\overline{\bar{x}}$ & $\overline{\bar{x}}$ & $\overline{\bar{x}}$ & $\overline{\bar{x}}$ & $\overline{\bar{x}}$ \\
\hline Soccer & 31 & 3.55 & 3.21 & 3.89 & 4.27 & 4.29 \\
\hline Basketball & 13 & 3.80 & 4.07 & 4.26 & 4.60 & 4.76 \\
\hline Volleyball & 17 & 3.82 & 2.86 & 3.94 & 4.36 & 4.54 \\
\hline Handball & 3 & 3.20 & 4.22 & 3.50 & 3.86 & 4.46 \\
\hline Swimming & 8 & 3.55 & 3.25 & 3.84 & 3.90 & 4.17 \\
\hline Racket sports & 4 & 4.50 & 4.08 & 4.18 & 4.40 & 4.85 \\
\hline Athletism & 10 & 3.70 & 3.10 & 3.77 & 4.48 & 4.38 \\
\hline Gymnastics & 4 & 4.00 & 2.83 & 3.68 & 4.25 & 4.50 \\
\hline Defense sports & 2 & 3.90 & 3.00 & 4.37 & 4.60 & 4.80 \\
\hline Total & 92 & 3.71 & 3.31 & 3.94 & 4.32 & 4.45 \\
\hline
\end{tabular}

Table 4

Average Scores of Physical Education Teachers Personality Traits According to Sports Types

\begin{tabular}{llccc}
\hline \multirow{2}{*}{ Personality factors } & \multicolumn{3}{c}{ Sports type } \\
\cline { 2 - 5 } & \multicolumn{3}{c}{ Team sports } & \multicolumn{3}{c}{ Individual sports } \\
\cline { 2 - 5 } & $N$ & $\bar{x}$ & $\overline{\bar{x}}$ \\
\hline Openness to experience & 64 & 3.65 & 28 & 3.82 \\
Emotional stability & 64 & 3.34 & 28 & 3.23 \\
Extroversion & 64 & 3.96 & 28 & 3.88 \\
Compatibility & 64 & 4.34 & 28 & 4.27 \\
Responsibility consciousness & 64 & 4.46 & 28 & 4.43 \\
\hline
\end{tabular}

A significant difference was found between the compatibility and emotional stability personality traits of the research group and sports branches $(p>0.05)$. However, there was no significant difference found between openness to experience, extroversion, and responsibility consciousness personality traits and sports branches $(p<0.05)$ (see Table 5).

There was no significant difference between the personality traits of the research group and sports types $(p<0.05)$ (see Table 6). 
Table 5

Kruskall-Wallis Test Performed for the Relationship Between Personality Traits of Physical Education Teachers and Sports Branches

\begin{tabular}{llrllll}
\hline Personality property & Sports branch & $N$ & Mean rank & $x^{2}$ & $d f$ & $p$ \\
\hline & Soccer & 31 & 43.92 & & & \\
Basketball & 13 & 71.85 & & & \\
Volleyball & 17 & 32.76 & & & \\
& Handball & 3 & 76.67 & & & \\
& Swimming & 8 & 43.56 & 28.633 & 8 & $0.000^{*}$ \\
& Racket sports & 4 & 74.00 & & & \\
& Athletism & 10 & 36.15 & & & \\
Gymnastics & 4 & 29.25 & & & \\
& Defense sports & 2 & 36.25 & & & \\
& Soccer & 31 & 42.89 & & & \\
Basketball & 13 & 64.50 & & & \\
& Volleyball & 17 & 48.38 & & & \\
& Handball & 3 & 24.33 & & & \\
& Swimming & 8 & 19.38 & 19.957 & & \\
& Racket sports & 4 & 49.62 & & & \\
& Athletism & 10 & 56.95 & & & \\
& Gymnastics & 4 & 40.75 & & & \\
\hline
\end{tabular}

Note. ${ }^{*} p<0.05$.

Table 6

Mann-Whitney U Test Performed for the Relationship Between Personality Traits of Physical Education Teachers and Sprots Types

\begin{tabular}{|c|c|c|c|c|c|c|}
\hline Personality traits & Sports type & $N$ & Mean rank & Sum of ranks & $p$ & $Z$ \\
\hline \multirow{2}{*}{ Openness to experience } & Team sports & 64 & 44.20 & $2,828.50$ & \multirow{2}{*}{0.208} & \multirow{2}{*}{-1.259} \\
\hline & Individual sports & 28 & 51.77 & $1,449.50$ & & \\
\hline \multirow{2}{*}{ Extroversion } & Team sports & 64 & 47.62 & $3,047.50$ & \multirow{2}{*}{0.540} & \multirow{2}{*}{-0.612} \\
\hline & Individual sports & 28 & 43.95 & $1,230.50$ & & \\
\hline \multirow{2}{*}{ Emotional stability } & Team sports & 64 & 48.16 & $3,082.50$ & \multirow{2}{*}{0.362} & \multirow{2}{*}{-0.912} \\
\hline & Individual sports & 28 & 42.70 & $1,195.50$ & & \\
\hline \multirow{2}{*}{ Compatibility } & Team sports & 64 & 47.87 & $3,063.50$ & \multirow{2}{*}{0.453} & \multirow{2}{*}{-0.750} \\
\hline & Individual sports & 28 & 43.38 & $1,214.50$ & & \\
\hline \multirow{2}{*}{ Responsibility consciousness } & Team sports & 64 & 46.52 & $2,977.50$ & \multirow{2}{*}{0.990} & \multirow{2}{*}{-0.013} \\
\hline & Individual sports & 28 & 46.45 & $1,300.50$ & & \\
\hline
\end{tabular}

\section{Discussion and Conclusion}

As for the study of physical education teachers' sports branches and their personality traits' averages, handball players received the lowest score in the sub-dimension of openness to experience, and tennis and badminton players received the highest score. In the emotional stability sub-dimension, gymnasts received the 
lowest average score and tennis and badminton players received the highest average score. In extroversion and compatibility sub-dimensions, handball players received the lowest score and defense sports received the highest score. In the responsibility consciousness, defense sports players received the highest score and swimmers received the lowest scores (see Table 3).

As a result of the evaluation made regarding the sports branches and personality traits of the physical education teachers, there was a significant difference between the emotional stability and compatibility $(p>0.05)$. Athletes, who received high scores in the emotional stability personality property, keep cool, do not have difficulty composing themselves, do not show their anger easily, are optimistic even when things do not go right, open to criticism, and do not have difficulty to resist to their desires and wishes. Athletes receiving high scores in the compatibility property approach their friends and opponents with good faith and are genuine, help others without expecting anything, keep the problems of others ahead of their own problems, and are supporters of collaborating with others and softhearted. There was no significant difference found in the other sub-dimensions, namely, openness to experience, extroversion, and responsibility consciousness personality traits $(p<0.05)$. Shariati and Bakhtiari (2011) were not able to find differences in the compatibility and openness to experience, and Yıldız, Tekin, and Lök (2009) did not find differences in the sub-dimensions of extroversion and neurotic traits.

There was no significant difference found between sports types of physical education teachers and personality traits. Therefore, it was concluded that sports types of the athletes do not affect their personalities. In the research conducted by Nia and Besharat (2010), there was no significant difference found between the extroversion personality property and sports types.

As for the averages of personality traits of the research group for sports types, it was observed that averages of emotional stability, extroversion, compatibility, and responsibility consciousness personality traits were higher in team sports in comparison to individual sports. Lata (2006) compared the personalities of athletes engaged in individual and team sports and reached the conclusion that responsibility personality characteristic of individual athletes was significantly different than team athletes. Nia and Besharat (2010) scrutinized personality characteristics of athletes active in individual and team sports and reported that scores of athletes engaged in individual sports were higher in responsibility and independent movement characteristics in comparison to those who are involved in team sports. In the research done by Hills and Argyle (1998), it was observed that the relationship between being extroversion and team sports was high. Moreover, it was seen that women athletes doing individual sports and participating in 1964 Olympics were more extroversion in comparison to women athletes doing team sports (Morgan, 1980). However, Nia and Besharat (2010) reported that this personality characteristic was higher in team sports in their study. In the research conducted by Gülü and Yentür (2008), it was found out that scores of the compatibility characteristics of the players of basketball, soccer, and handball (team sports) players were higher than scores of the judo players, wrestlers, and weight lifters (individual sports).

However, it was seen that in openness to experience personality property, average of individual sports was higher than team sports. In the research conducted by Nia and Besharat (2010), it was found out that the average of team sports was higher.

As for the lack of a significant difference between the branches of physical education teachers, individual and team sports, and their personalities, it is thought that since the physical education teachers act as a model or guide to students during the education process, thus, they become distant to their athlete identity and assume 
teacher identity. Furthermore, since many of the physical education teachers are not active in sports, this is thought to be one of the reasons for reaching this result.

\section{References}

Barrick, M. R., \& Mount, M. K. (1991). The big five personality dimensions and job performance: A meta-analysis. Personnel Psychology, 44(1), 1-26.

Berry, L. (1998). Psychology at work: An introduction to organizational psychology. New York, N.Y.: McGraw-Hill Book Company.

Burger, J. M. (2006). Personality. (İnan Deniz Erguvan Sarığlu Trans.). İstanbul: Kaknüs Yayınları.

Çamlıca, C. (2008). Orta öğretim okullarında okuyan öğrencilerin beden eğitimi dersi hakkındaki düşünceleri ve beklentileri (Thoughts and expectations of middle school students about the physical education class) (Master's thesis, Selçuk Üniversitesi). (In Turkish)

Dubrin, A. (1994). Applying psychology: Individual and organizational effectiveness. Upper Saddle River, N.J.: Prentice Hall.

Eken, D. (2008). İlköğretim II. Kademe öğrencilerinin beden eğitimi dersi hakkındaki düşünceleri ve beklentileri (Thoughts and expectations of secondary school students about the physical education class) (Master's thesis, Selçuk Üniversitesi). (In Turkish).

Erden, M. (2009). Eğitim bilimlerine giriş (Introduction to educational sciences). Ankara: Arkadaş Yayınevi. (In Turkish)

Ertuğrul, H. (2000). Öğretmenin başarı kılavuzu (Teachers' guide to success). İstanbul: Nesil Yayınları. (In Turkish)

Friedman, H. S., \& Schustack, M. W. (1999). Personality: Classic theories and modern research. Boston, M.A.: Allyn $\&$ Bacon.

Güçlü, M., \& Yentür, J. (2008). Milli takım düzeyindeki elit bayan sporcuların kişisel ve sosyal uyum düzeyleri ile bedenlerini algılama düzeylerinin karşılaştırılması (Comparison of the level of personal and social adaptation and of perception of body: The case of professional sportswomen in the national team). Spormetre Beden Eğitimi ve Spor Bilimleri Dergisi, VI(4), 183-192. (In Turkish)

Güllü, M. (2007). Ortaöğretim öğrencilerinin beden eğitimi dersine ilişkin tutumlarının araştırılması (An investigation into the attitudes of middle school students towards physical education class) (Unpublished doctorial dissertation, Gazi Üniversitesi). (In Turkish)

Hackett, R. S., \& Saha, S. (1999). Leadership emergence in autonomous work teams: Antecedents and outcomes. Personnel Psychology, 52, 899-926.

Hills, P., \& Argyle, M. (1998). Positive moods derived from leisure and their relationship to happiness and personality. Personality and Individual Differences, 25, 523-535.

Hjelle, L. A., \& Ziegler, D. J. (1976). Personality theories: Basic assumptions, research and applications. New York, N.Y.: McGraw-Hill Book Company.

Hughes, R. (1996). Leadership, enhancing the lessons of experience. New York, N.Y.: Donneley and Sons Company.

Karasar, N. (2003). Bilimsel araştırma yöntemi (Scientific research methodology). Ankara: Nobel Yayınları.

Köknel, Ö. (2005). Kaygıdan mutluluğa kişilik (Personality: From anxiety to happiness). İstanbul: Akdeniz Yayıncılık. (In Turkish)

Larsen, R. J., \& Buss, D. M. (2008). Personality psychology: Domains of knowledge about human nature. Boston, M.A.: McGraw-Hill Book Company.

Lata, J. W. (2006). An analysis of goal achievement orientation and sport morality levels of division I-A non-revenue collegiate athletes (Ph.D. dissertation, Florida State University).

Morgan, Ç. T. (1980). Introduction to psychology. (S. Karabaş Trans.). Ankara: Hacettepe University Psychology Department Publications.

Nia, M. E., \& Besharat, M. A. (2010). Comparison of athletes' personality characteristics in individual and team sports. Procedia-Social and Behavioral Sciences, 5, 808-812.

Özdemir, S., \& Yalın, İ. H. (2000). Öğretmenlik mesleğine giriş (Introduction to teaching). Ankara: Nobel Yayınevi. (In Turkish)

Sevinç, L. (2005). PERİ kişilik envanteri teknik kitapcı̆̆g (Technical booklet of PERI personality inventory). İstanbul: Assesment 
Systems Yayınları. (In Turkish)

Shariati, M., \& Bakhtiari, S. (2011). Comparison of personality characteristics athlete and non-athlete student, Islamic Azad University of Ahvaz. Procedia-Social and Behavioral Sciences, 30, 2312-2315.

Şişko, M., \& Demirhan, G. H. (2002). İlköğretim okulları ve liselerde öğrenim gören kız ve erkek öğrencilerin beden eğitimi ve spor dersine ilişkin tutumları (Attitudes of male and female students at primary, secondary and high schools towards physical education and sports class). H. Ü. Eğitim Fakültesi Dergisi, 23, 205-210. Retrieved September 12, 2013, from http://www.efdergi.hacettepe.edu. Obtained fromtr/200223METIN\%20 ŞIŞKO. pdf (In Turkish)

Tannehil, D., \& Zekrajsek, D. (1993). Student attitudes toward physical education: A multicultural study. Journal of Teaching Physical Education, 13, 78-84.

Yıldız, M. M., Tekin, M., \& Lök, S. (2009). Farklı statüdeki futbolcuların kişilik tiplerinin incelenmesi (Investigation of personality types of footballers with varying qualifications). Selçuk Üniversitesi Spor Bilimleri Enstitüsü Dergisi, 22, 437-443. (In Turkish)

Zel, U. (2001). Kişilik ve liderlik (Personality and leadership). Ankara: Seçkin Yayınları. (In Turkish) 